\title{
Haematological Indices of Vanraja Poultry Birds Fed Aloe vera (Aloe barbadensis) and Neem (Azadirachta indica) Leaves Powder
}

\author{
S. D. Gadekar*, S. D. Chavan and S. P. Nage \\ Department of Animal Husbandry and Dairy science, Dr. Panjabrao Deshmukh Krishi \\ Vidyapeeth, Akola, (M. S.), India \\ *Corresponding author
}

\begin{tabular}{|l|}
\hline Key w or d s \\
Aloe vera, Neem, \\
Haematological, \\
Vanraja
\end{tabular}

\begin{abstract}
A B S T R A C T
To determine the effect of using Aloe vera and Neem leaves powder on carcass characteristics and some haematological parameters in vanraja poultry birds, a total 270 a day old chicks with an average identical weight were divided into 9 treatments with 3 replicates as factorial randomized block design experiment. The birds were fed by basal diet as control diet, Aloe vera, Neem leaves powder based diet and different combinations of aloe vera and neem leaves powder. On the basis of data obtained on haematobiochemical parameters, there was significantly increased in haemoglobin values in $\mathrm{T}_{6}$ $(11.70 \mathrm{~g} / \mathrm{dl})$ followed by $\mathrm{T}_{8}(11.10 \mathrm{~g} / \mathrm{dl}), \mathrm{T}_{2}$ and $\mathrm{T}_{5}(10.90 \mathrm{~g} / \mathrm{dl}), \mathrm{T}_{9}(10.80), \mathrm{T}_{7}(10.76 \mathrm{~g} / \mathrm{dl})$, $\mathrm{T}_{4}(10.48 \mathrm{~g} / \mathrm{dl})$ and lowest in $\mathrm{T}_{1}(9.11 \mathrm{~g} / \mathrm{dl})$. The PCV count was 28.72, 29.97, 33.63, $31.80,32.81,37.72,32.97,32.96$ and 32.95 per cent for treatment groups $\mathrm{T}_{1}, \mathrm{~T}_{2}, \mathrm{~T}_{3}, \mathrm{~T}_{4}, \mathrm{~T}_{5}$, $\mathrm{T}_{6}, \mathrm{~T}_{7}, \mathrm{~T}_{8}$ and $\mathrm{T}_{9}$, respectively. It was revealed that the PCV count of treatment group $\mathrm{T}_{6}$ (37.72 per cent) was significantly $(\mathrm{P}<0.05)$ higher than all groups. The $\mathrm{RBC}$ count was $2.75,2.87,2.59,2.89,2.87,2.93,2.75,2.73$ and $2.7310^{6} / \mathrm{mm}^{3}$ for the treatment groups $\mathrm{T}_{1}$, $\mathrm{T}_{2}, \mathrm{~T}_{3}, \mathrm{~T}_{4}, \mathrm{~T}_{5}, \mathrm{~T}_{6}, \mathrm{~T}_{7}, \mathrm{~T}_{8}$ and $\mathrm{T}_{9}$, respectively. Thus, there were significant $(\mathrm{P}<0.05)$ increase $\mathrm{RBC}$ values in respective treatments. The WBC count was $35148.69,36236.05$, $35172.08,35282.31,33651.07,36418.06,35062.18,34778.28$ and $34609.48 \mathrm{Cells} / \mathrm{mm}^{3}$ for the treatment groups $\mathrm{T}_{1}, \mathrm{~T}_{2}, \mathrm{~T}_{3}, \mathrm{~T}_{4}, \mathrm{~T}_{5}, \mathrm{~T}_{6}, \mathrm{~T}_{7}, \mathrm{~T}_{8}$ and $\mathrm{T}_{9}$, respectively. Thus, there were significant increase WBC values in respective treatments. $\mathrm{T}_{6}(36418.18) \mathrm{Cells} / \mathrm{mm}^{3}$ had the highest WBC level among the treatments. As result relevant from this study using of Aloe vera and Neem leaves powder in diet may be useful and have significantly effects on some blood biochemical parameters on Vanraja poultry birds.
\end{abstract}

\section{Introduction}

Poultry farming is the raising of domesticated birds such as chickens, Duck, Turkey, and Gees for the purpose of meat or eggs for feed. Poultry industry is a fast growing segment of the agriculture sector in the world. Modern intensive poultry industry demands more

rapid growth in a confined housing
environment which leads to greater
susceptibility to stress in birds.

Poultry industry has made a tremendous and remarkable progress evolving from a small scale backyard venture to the status of commercial, full fledge, self-sufficient and 
most progressive agro based industry and become an attractive enterprise particularly because of the small capital investment, increased returns, quick turn over, comparatively less risk involved, low land requirement, ease of production and high feed efficiency. Due to increasing demand for poultry meat, short supply of mutton and limited acceptability of beef and pork in some countries as considering of religious and cultural points like India. The poultry production is under rapid expansion in the world. Chickens are much more prolific than other livestock and through careful scientific breeding policies; they have become efficient converters of vegetables protein into high quality animal protein food for human consumption.

Feed supplement and feed additives has served the purpose of best production efficiencies over the years. Potential of birds is fully utilized by such feed formulation and feeding practices. At present numbers of feed additives are used to feed broiler birds for the purpose of increase in body weight gain and improve feed efficiency (FCR). However, availability of quality feed at the reasonable cost is key to successful poultry operation (Basak et al., 2002). In view of this to overcome problems of quality feed it is prime important to add some feed additives as a growth promoters. However some additives like hormones, probiotics, antibiotics and others with the aim to increase the feed efficiency, have residual effects. They leave their residue in meat and egg. Among all these, herbal feed additives are better for feeding of poultry to improve weight gain, feed efficiency and feed intake. These herbal feed additives have no side effects on the health of birds. The dietary use of herbal growth promoter increases the performance of poultry by increasing live weight gain and FCR (Prasad and Sen. 1993, Samarth et al., 2002). In this regards objectives are set to study the use of certain growth promoting herbal feed additives like Aloe vera and Neem.

\section{Materials and Methods}

\section{Birds and diets}

The experiment was conducted on 270 , day old Vanraja chicks, the birds were from the same hatch and were reared under uniform management condition. On arrival, the chicks were weighed individually and randomly divided into nine treatments with three replications, each replication has ten birds.

For the experiment, commercial pre starter, starter and finisher feed were used as basal diet, used as basal diet.

\section{Chemical composition of herbal feed additives (\% DM basis)}

Aloe vera powder used in present investigation contained 83.61, 6.86, 2.91, 73.35 , and 16.88 per cent of dry matter, crude protein crude fat, crude fibre and total ash respectively. Similarly, Neem leaves powder contained 92.40, 20.68, 4.13, 16.60 and 7.10 per cent of dry matter, crude protein, crude fat, crude fibre and total ash respectively (Table 1).

Preparation of Aloe vera powder the leaves were thoroughly wash with tap water, then slicing of leaves were done followed by drying of Aloe vera slices in desiccant dehumidified air dryer at temperature of 60$65{ }^{0} \mathrm{C}$ and $\mathrm{RH}$ of 18 per cent then dehydrated slices were ground in low temperature grinder to obtain Aloe vera leaves powder, at Department of Agriculture Processing Engineering, Dr, P.D.K.V., Akola. The powder was stored in air tight cellophane bag as stock sample in refrigerator for further analysis. The fresh, clean and succulent green 
Neem leaves were put in tray for drying and these fresh leaves were keep in mechanical tray dryer machine for drying at $40^{\circ} \mathrm{C}$ for $2-4$ hours at Department of Agriculture Processing Engineering, Dr, P.D.K.V., Akola (Table 2).

\section{Dietary treatments}

\begin{tabular}{|c|c|c|c|c|c|c|c|}
\hline $\mathbf{T}_{\mathbf{1}}$ & Standard Ration & & \multicolumn{5}{|c|}{ Control } \\
\hline $\mathbf{T}_{\mathbf{2}}$ & Standard Ration & + & $\mathbf{1 \%}$ & $\mathbf{A V P}$ & & & \\
\hline $\mathbf{T}_{\mathbf{3}}$ & Standard Ration & + & $\mathbf{2 \%}$ & $\mathbf{A V P}$ & & & \\
\hline $\mathbf{T}_{\mathbf{4}}$ & Standard Ration & + & $\mathbf{1 \%}$ & $\mathbf{N L P}$ & & & \\
\hline $\mathbf{T}_{\mathbf{5}}$ & Standard Ration & + & $\mathbf{1 . 5 \%}$ & $\mathbf{N L P}$ & & & \\
\hline $\mathbf{T}_{\mathbf{6}}$ & Standard Ration & + & $\mathbf{1 \%}$ & $\mathbf{A V P}$ & + & $\mathbf{1 \%}$ & $\mathbf{N L P}$ \\
\hline $\mathbf{T}_{\mathbf{7}}$ & Standard Ration & + & $\mathbf{1 \%}$ & $\mathbf{A V P}$ & + & $\mathbf{1 . 5 \%}$ & $\mathbf{\text { NLP }}$ \\
\hline $\mathbf{T}_{\mathbf{8}}$ & Standard Ration & + & $\mathbf{2 \%}$ & $\mathbf{A V P}$ & + & $\mathbf{1 \%}$ & $\mathbf{N L P}$ \\
\hline $\mathbf{T}_{\mathbf{9}}$ & Standard Ration & + & $\mathbf{2 \%}$ & $\mathbf{A V P}$ & + & $\mathbf{1 . 5 \%}$ & $\mathbf{N L P}$ \\
\hline
\end{tabular}

Where,

AVP - Aloe vera Powder

NLP- Neem Leaves Powder

\section{Collection of blood samples}

At the end of experiment, one bird from each replication was randomly picked up and blood samples were collected for hematological and serum biochemical analysis.

The blood samples were collected at the end of $8^{\text {th }}$ week of age from wing vein with syringe from one bird in each replication. The blood collected in sterilized glass test tube kept in a slant position and serum was separated. All the serum samples was stored in deep freezed at $20^{\circ} \mathrm{C}$ until processed.

All samples of serum were analyzed at department of Veterinary Biochemistry, PGI, VAS, MAFSU, Akola.

\section{Statistical analysis}

The statistical analysis of the data obtained during experimental period was carried out as per Snedecor and Cochran (1994) using Factorial Randomized Block Design and Randomized Block Design.

\section{Results and Discussion}

\section{Haemato-biochemical parameters}

To combat the clinical and subclinical forms of poultry diseases, accurate and differential diagnosis of the diseases at early stages of infections is necessary. Measurement of haematological parameters provides valuable information in this regards.

\section{Haemoglobin}

Haemoglobin in blood carries oxygen from the lungs or gills to the rest of the body (i.e. the tissues). There it releases the oxygen to permit aerobic respiration to provide energy to power the functions of the organism in the process called metabolism. From the data, it was observed that the haemoglobin was 9.11 , $10.90,10.91,10.48,10.90,11.70,10.76$, 11.10 and 10.80 for treatment groups $T_{1}, T_{2}$, $\mathrm{T}_{3}, \mathrm{~T}_{4}, \mathrm{~T}_{5}, \mathrm{~T}_{6}, \mathrm{~T}_{7}, \mathrm{~T}_{8}$ and $\mathrm{T}_{9}$, respectively. Thus there was significantly increased in serum haemoglobin values in $\mathrm{T}_{6} \quad(11.70$ $\mathrm{mg} / \mathrm{dl})$ followed by $\mathrm{T}_{8}(11.10 \mathrm{~g} / \mathrm{dl}), \mathrm{T}_{2}$ and $\mathrm{T}_{5}$ $(10.90 \mathrm{~g} / \mathrm{dl}), \mathrm{T}_{9}(10.80), \mathrm{T}_{7}(10.76 \mathrm{~g} / \mathrm{dl}), \mathrm{T}_{4}$ $(10.48 \mathrm{~g} / \mathrm{dl})$ and lowest in $\mathrm{T}_{1}(9.11 \mathrm{~g} / \mathrm{dl})$. All treatments were at par with each other. It was revealed that the haemoglobin value of group $\mathrm{T}_{6}(11.70 \mathrm{~g} / \mathrm{dl})$ was significantly higher than all groups (Table 3 ). 
Table.1 Per cent chemical composition of experimental standard ration on dry matter basis

\begin{tabular}{|c|l|c|c|c|}
\hline \multirow{2}{*}{$\begin{array}{c}\text { Sr. } \\
\text { No. }\end{array}$} & \multicolumn{1}{|c|}{ Nutrients } & \multicolumn{3}{c|}{ Per cent in ration } \\
\cline { 2 - 4 } & & Pre-starter & Starter & Finisher \\
\hline $\mathbf{1}$ & Crude protein & 22 & 20 & 18 \\
\hline $\mathbf{2}$ & Crude fibre & 6.0 & 6.0 & 5.5 \\
\hline $\mathbf{3}$ & Ether extract & 62.2 & 65 & 67.5 \\
\hline $\mathbf{4}$ & Total ash & 6.5 & 6.0 & 5.0 \\
\hline $\mathbf{5}$ & Acid insoluble ash & 1.50 & 2.0 & 2.0 \\
\hline $\mathbf{6}$ & Calcium & 1.0 & 1.0 & 0.9 \\
\hline $\mathbf{7}$ & Phosphorous & 0.5 & 0.5 & 0.5 \\
\hline $\mathbf{8}$ & Metabolizable energy $(\mathrm{kcal} / \mathrm{kg})$ & 2600 & 2700 & 2800 \\
\hline $\mathbf{9}$ & E/P ratio & $118.18: 1$ & $135: 1$ & $155.55: 1$ \\
\hline
\end{tabular}

Table.2 Chemical compositions of herbal feed additives (\% DM basis) dietary treatments

\begin{tabular}{|c|c|c|}
\hline Parameter & Aloe vera leaf powder & Neem leaf powder \\
\hline Dry matter & 83.61 & 92.40 \\
\hline Crude protein & 6.86 & 20.68 \\
\hline Crude fat & 2.91 & 4.13 \\
\hline Crude fibre & 73.35 & 16.60 \\
\hline Ash & 16.88 & 7.10 \\
\hline
\end{tabular}

Table.3 Effect of supplementation of Aloe vera and Neem leaves powder on haemoglobin (g/ dl) under different treatment groups

\begin{tabular}{|c|c|}
\hline Treatments & Haemoglobin $(\mathbf{g} / \mathbf{d l})$ \\
\hline $\mathbf{T}_{\mathbf{1}}$ & $9.11^{\mathrm{d}}$ \\
\hline $\mathbf{T}_{\mathbf{2}}$ & $10.90^{\mathrm{bc}}$ \\
\hline $\mathbf{T}_{\mathbf{3}}$ & $10.91^{\mathrm{bc}}$ \\
\hline $\mathbf{T}_{\mathbf{4}}$ & $10.48^{\mathrm{c}}$ \\
\hline $\mathbf{T}_{\mathbf{5}}$ & $10.90^{\mathrm{bc}}$ \\
\hline $\mathbf{T}_{\mathbf{6}}$ & $11.70^{\mathrm{a}}$ \\
\hline $\mathbf{T}_{\mathbf{7}}$ & $10.76^{\mathrm{bc}}$ \\
\hline $\mathbf{T}_{\mathbf{8}}$ & $11.10^{\mathrm{b}}$ \\
\hline $\mathbf{T}_{\mathbf{9}}$ & $10.80^{\mathrm{bc}}$ \\
\hline $\mathbf{S . E .}$ & 0.17 \\
\hline C.D. @ $\mathbf{5}$ per cent & 0.527 \\
\hline C. $\mathbf{V}$. $\%$ & 2.836 \\
\hline
\end{tabular}

Means with different superscripts differ significantly 
Table.4 Effect of supplementation of Aloe vera and Neem leaves powder on PCV count under different treatment groups

\begin{tabular}{|c|c|}
\hline Treatments & PCV (\%) \\
\hline $\mathbf{T}_{\mathbf{1}}$ & $28.72^{\mathrm{g}}$ \\
\hline $\mathbf{T}_{\mathbf{2}}$ & $29.97^{\mathrm{f}}$ \\
\hline $\mathbf{T}_{\mathbf{3}}$ & $33.63^{\mathrm{b}}$ \\
\hline $\mathbf{T}_{\mathbf{4}}$ & $31.80^{\mathrm{e}}$ \\
\hline $\mathbf{T}_{\mathbf{5}}$ & $32.81^{\mathrm{d}}$ \\
\hline $\mathbf{T}_{\mathbf{6}}$ & $37.72^{\mathrm{a}}$ \\
\hline $\mathbf{T}_{\mathbf{7}}$ & $32.97^{\mathrm{c}}$ \\
\hline $\mathbf{T}_{\mathbf{8}}$ & $32.96^{\mathrm{c}}$ \\
\hline $\mathbf{T}_{\mathbf{9}}$ & $32.95^{\mathrm{c}}$ \\
\hline S.E. & 0.036 \\
\hline C.D. @ 5 per cent & 0.118 \\
\hline C.V.\% & 0.204 \\
\hline
\end{tabular}

Means with different superscripts differ significantly

Table.5 Effect of supplementation of Aloe vera and Neem leaves powder on RBC count $\left(10^{6} \%\right.$ $\mathrm{mm}^{3}$ ) under different treatment groups

\begin{tabular}{|c|c|}
\hline Treatments & RBC $\left(\mathbf{1 0}^{\mathbf{6}} / \mathbf{m m}^{\mathbf{3}}\right)$ \\
\hline $\mathbf{T}_{\mathbf{1}}$ & $2.75^{\mathrm{b}}$ \\
\hline $\mathbf{T}_{\mathbf{2}}$ & $2.87^{\mathrm{a}}$ \\
\hline $\mathbf{T}_{\mathbf{3}}$ & $2.59^{\mathrm{c}}$ \\
\hline $\mathbf{T}_{\mathbf{4}}$ & $2.89^{\mathrm{a}}$ \\
\hline $\mathbf{T}_{\mathbf{5}}$ & $2.87^{\mathrm{a}}$ \\
\hline $\mathbf{T}_{\mathbf{6}}$ & $2.93^{\mathrm{a}}$ \\
\hline $\mathbf{T}_{\mathbf{7}}$ & $2.75^{\mathrm{b}}$ \\
\hline $\mathbf{T}_{\mathbf{8}}$ & $2.73^{\mathrm{b}}$ \\
\hline $\mathbf{T}_{\mathbf{9}}$ & $2.73^{\mathrm{b}}$ \\
\hline $\mathbf{S . E .}$ & 0.026 \\
\hline C.D. @ $\mathbf{5}$ per cent & 0.078 \\
\hline C. $\mathbf{V . \%}$ & 1.611 \\
\hline
\end{tabular}

Means with different superscripts differ significantly

Table.6 Effect of supplementation of Aloe vera and Neem leaves powder on WBC count (cell/ $\mathrm{mm}^{3}$ ) under different treatment groups

\begin{tabular}{|c|c|}
\hline Treatments & WBC $\left(\right.$ cells $\left./ \mathbf{m m}^{\mathbf{3}}\right)$ \\
\hline $\mathbf{T}_{\mathbf{1}}$ & $35148.69^{\mathrm{b}}$ \\
\hline $\mathbf{T}_{\mathbf{2}}$ & $36236.05^{\mathrm{a}}$ \\
\hline $\mathbf{T}_{\mathbf{3}}$ & $35172.08^{\mathrm{b}}$ \\
\hline $\mathbf{T}_{\mathbf{4}}$ & $35282.31^{\mathrm{b}}$ \\
\hline $\mathbf{T}_{\mathbf{5}}$ & $33651.07^{\mathrm{d}}$ \\
\hline $\mathbf{T}_{\mathbf{6}}$ & $36418.06^{\mathrm{a}}$ \\
\hline $\mathbf{T}_{\mathbf{7}}$ & $35062.18^{\mathrm{b}}$ \\
\hline $\mathbf{T}_{\mathbf{8}}$ & $34778.28^{\mathrm{c}}$ \\
\hline $\mathbf{T}_{\mathbf{9}}$ & $34609.48^{\mathrm{c}}$ \\
\hline S.E. & 425.683 \\
\hline C.D. @ 5 per cent & 1281.43 \\
\hline C.V.\% & 2.09754 \\
\hline
\end{tabular}

Means with different superscripts differ significantly 
The results of present study with respect to haemoglobin were in agreement with results of Mmereole (2011) they reported that hb level were increased significantly $(\mathrm{P}<0.05)$ when birds fed up to 1 per cent aloe vera powder diet compared to control diet, also Ansari et al., (2012) reported broiler chicks with Azardirachta indica leaf meal at three supplementary levels of meal up to $2.5 \mathrm{~g} / \mathrm{kg}$ had higher $(\mathrm{p}<0.05) \mathrm{Hb}$ concentrations than birds fed diets without leaf meal (negative control) and third dose of leaf meal. Further, Obikaonu et al., (2012) and Morshedul et al., (2015) reported there were no significant differences $(\mathrm{P}>0.05)$ among the $\mathrm{Hb}$ values in different treatment groups when neem leaf powder fed up 2.5, 5 and 7.5 per cent level.

\section{Packed cell volume}

The packed cell volume (PCV) reference intervals were established for use in diagnosing anemia and polycethemia in young poultry birds. The average packed cell volume (PCV) values (per cent) in different groups are presented in Table 4.

From the data, it was observed that the PCV was $28.72,29.97,33.63,31.80,32.81,37.72$, 32.97, 32.96 and 32.95 per cent for treatment groups $\mathrm{T}_{1}, \mathrm{~T}_{2}, \mathrm{~T}_{3}, \mathrm{~T}_{4}, \mathrm{~T}_{5}, \mathrm{~T}_{6}, \mathrm{~T}_{7}, \mathrm{~T}_{8}$ and $\mathrm{T}_{9}$, respectively. Thus there was significant increase in PCV count in all treatment groups as compared to treatment group $\mathrm{T}_{1}$.

It was revealed that the PCV of treatment group $\mathrm{T}_{6}$ (37.72 per cent) was significantly $(\mathrm{P}<0.05)$ higher than all groups. Hence treatment $\mathrm{T}_{6}$ was significant over other treatments followed by $\mathrm{T}_{3}(33.63$ per cent $), \mathrm{T}_{7}$ (32.97 per cent), $\mathrm{T}_{8}$ (32.96 per cent), $\mathrm{T}_{9}$ (32.95 per cent), $\mathrm{T}_{5}$ (32.81 per cent), $\mathrm{T}_{4}$ (31.80 per cent), $T_{2}$ (29.97 per cent) and $T_{1}$ (28.72 per cent). Treatment $\mathrm{T}_{1}, \mathrm{~T}_{2}, \mathrm{~T}_{3}, \mathrm{~T}_{4}, \mathrm{~T}_{5}$, $\mathrm{T}_{6}, \mathrm{~T}_{7}, \mathrm{~T}_{8}$ and $\mathrm{T}_{9}$ was at par with each other.
The results of the present study with respect on PCV were in agreement with Mmereole et al., (2011) evaluate the effect of dietary inclusion of Aloe the results of PCV count of experimental birds showed that there were significant $\quad(\mathrm{p}<0.05) \quad$ difference in haematological parameters among different diet groups, also Singh et al., (2013) had reported that fresh Aloe vera leaf juice $(20 \mathrm{~g} / \mathrm{L})$ significantly $(\mathrm{p}<0.05)$ higher $\mathrm{PCV}$ value than other treatment groups.

Esonu et al., (2006) feeding Neem (Azadirachta indica) leaf meal (NLM) birds fed diet with 10 per cent Neem leaf meal recorded the highest haemoglobin value of $12.0 \mathrm{~g} / 100 \mathrm{ml}$, packed cell volume (PCV) of layers in the 10 per cent treatment group differed significantly from that control treatment group, similarly Ansari et al., (2012) and Bonsu et al., (2012) Obikaonu et al., (2012) fed on diets containing antibiotic and leaf meal had higher $(\mathrm{p}<0.05)$ PCV over other treatment groups.

On contrary, Alam et al., (2014) reported that there were no any significant difference $(\mathrm{P}>0.05)$ on PCV count between the control and polyherbal (NNTT extract) treated groups, also Alam et al., (2015) did not show any significant difference $(\mathrm{P}<0.05)$ between neem leaves powder based diet and other treatment groups for PCV.

\section{Red blood cells ( RBC)}

Spleen stores RBC in mammals, but in birds RBC stores in bone marrow. The primary function of red blood cells, or erythrocytes, is to carry oxygen from the lungs to the body tissues and carbon dioxide as a waste product, away from the tissues and back to the lungs. Haemoglobin $(\mathrm{Hb})$ is an important protein in the red blood cells that carries oxygen from the lungs to all parts of our body. 
The average Red blood cells (RBC) count $\left(10^{6 / \mathrm{mm}^{3}}\right)$ in different groups are presented in Table 5.

From the data, it was observed that the RBC count was 2.75, 2.87, 2.59, 2.89, 2.87, 2.93, 2.75, 2.73 and $2.7310^{6} / \mathrm{mm}^{3}$ for the treatment groups $\mathrm{T}_{1}, \mathrm{~T}_{2}, \mathrm{~T}_{3}, \mathrm{~T}_{4}, \mathrm{~T}_{5}, \mathrm{~T}_{6}, \mathrm{~T}_{7}, \mathrm{~T}_{8}$ and $\mathrm{T}_{9}$, respectively. Thus, there were significant increase $\mathrm{RBC}$ count in respective treatments. $\mathrm{T}_{6}$ (2.93) $10^{6} / \mathrm{mm}^{3}$ had the highest RBC count among the treatments.

Present findings of the study are in agreement with Esonu et al., (2006) found the significant difference in RBC count of birds on fed $0 \% 10$ per cent and 15 per cent inclusion levels of neem leaf meal, simillarly Ismail (2017); Ansari et al., (2012) reported significant $(\mathrm{P}<0.05)$ increase in RBC count while supplementing Azadirachta indica i.e. neem leaves aqueous extract to broiler chicken.

On contrary Nodu et al., (2016); Trincha et al., (2012); Bonsu et al., (2012) and Alam et al., (2015) showed no significant $(\mathrm{P}>0.05)$ influenced in $\mathrm{RBC}$ values are in tandem with normal ranges reported for healthy birds. This implies that the use of neem and aloe vera leaf powder as supplement in chicken production is both safe and healthy.

\section{White blood cells}

White blood cells (also called leukocytes or leucocytes and abbreviated as WBCs) are the cells of the immune system that are involved in protecting the body against both infectious disease and foreign invaders. The values of WBC in birds possess phagocytic function and used as an indicator of stress response and sensitive biomarkers crucial to immune function.

The average White blood cells (WBC) count $\left(\right.$ Cells $\left./ \mathrm{mm}^{3}\right)$ in different groups are presented in Table 6 From the data, it was observed that the WBC count was $35148.69,36236.05,35172.08$, $35282.31, \quad 33651.07, \quad 36418.06, \quad 35062.18$,
34778.28 and 34609.48 Cells/ $\mathrm{mm}^{3}$ for the treatment groups $\mathrm{T}_{1}, \mathrm{~T}_{2}, \mathrm{~T}_{3}, \mathrm{~T}_{4}, \mathrm{~T}_{5}, \mathrm{~T}_{6}, \mathrm{~T}_{7}, \mathrm{~T}_{8}$ and $\mathrm{T}_{9}$, respectively. Thus, there were significant increase $\mathrm{WBC}$ count in respective treatments. $\mathrm{T}_{6}$ (36418.06) Cells/ $\mathrm{mm}^{3}$ had the highest WBC count among the treatments.

Present findings of the study are in agreement with Mmereole et al., (2011) reported dietary inclusion of Aloe vera on haematological analysis of experimental birds showed that there were significant $(\mathrm{p}<0.05)$ difference in haematological parameters among different diet groups. The WBC count was significantly $(\mathrm{p}<0.05)$ higher than WBC count in control group, also Bonsu et al., (2012); Obikaonu et al., (2012) who reported WBC count was significantly influenced by NLM than control group, similarly Esonu et al., (2006) found the significant difference in RBC count of birds on fed 0 per cent, 10 per cent and 15 per cent inclusion levels of neem leaf meal.

On contrary, Ansari et al., (2012) reported that WBC clearly points to the fact that the birds on $5 \mathrm{~g} / \mathrm{kg}$ leaf meal were stressed hence the significant $(\mathrm{p}<0.05)$ reduction in WBC. This tends to confirm the report of Talebi et al., (2005) that nutrition affects the blood profiles of birds and this implies that up to $2.5 \%$ inclusion of leaf meal had a positive effect on the relative quantity of blood cell as well as total volume of blood.

\section{References}

Alam, M. M.; A. T. M. F. K. Rakib, M. A. A. Hassan, M. S. Hasan and M. A. Ali, 2015. Effects of neem leave powder as a growth promoter in broilers. International Journal of Natural and Social Sciences, 2(2): 2226.

Alam, M. N.; J. Uddin, M. T. D. Akter, M. I. Z. Moni, F. Alom, A. Rahman, and M. A. A. Noman, 2014. Broiler production by using polyherbal medication (neem, nishyinda, tulsi and turmeric extract). International Journal of Innovation and Applied Studies, 9(3): 1161-1175. 
Ansari, J.; S. H. Khan, A. U. Haq and M. Yousaf, 2012. Effect of the levels of Azadirachtaindica dried leaf meal as phytogenic feed additive on the growth performance and haemato-biochemical parameters in broiler chicks, Journal of Applied Animal Research, 40 (4): 336345.

Basak B.; A. H. Pramanik, M. S. Rahman, S. U. Tarafdar and B. C. Roy, 2002. Azolla (Azollapinnata) as a feed ingredient in boiler ration. Int. J. Poult. Sci., 1(1/3): 2934.

Bonsu, F. R. K.; K. Agyemang, W. K. J. Kwenin and H. K. Zanu, 2012. Medicinal response of broiler chickens to diets containing neem (Azadirachta indica) leaf meal, haematology and meat sensory analysis. World Applied Sciences Journal, 19 (6): 800-805.

Esonu, B. O.; M. N. Opara, I. C. Okoli, H. O. Obikaonu, C. Udedibie, O. O. M. Iheshiulor, 2006. Physiological response of laying birds to neem (Azadirachta indica) leaf meal-based diets: body weight organ characteristics and haematology. Online Journal of Health and Allied Science, 5(2): 2-4.

Ismail, H. T. K.; 2017. Biochemical and hematological studies on the effect of neem (Azadirachta indica) leaves aqueous extract on Newcastle disease vaccine and infection in broiler chickens. International journal of recent scientific research. 8 (3): 15876-15884.

Mmereole, F. U. C., 2011. Evaluation of the dietary inclusion of aloe vera as an alternative to antibiotic growth promoter in broiler production. Pakistan Journal of Nutrition, 10 (1): 1-5.

Morshedul A.; A.T.M. Rakib, Md. AbdullahAl-Hasan, Md. SaifulHasan, Md. Ashraf Ali, 2015. Effect of neem leaves powder as a growth promoter in broilers. Int. J. of Natural and Soc. Sci., 2(2):22-26.

Nodu, M. B.; M. Okpeku, Z. A. Akpovetai and D. O. Iroegbu, 2016. Evaluation of azadirachta indica leave extract on hematology and biochemical profiles, organs weight and growth parameters of broiler chickens. Journal of new sciences, 32(5): 1879-1884.

Obikaonu, H.O.; I. C. Okoli, M.N. Opara, V. M. O. Okoro, I.P. Ogbuewu, E.B. Etuk and A.B.I. Udedibie, 2012. Haematological and serum biochemical indices of starter broilers fed leaf meal of neem (Azadirachta indica). Journal of Agricultural Technology, 8 (1): 71-79.

Prasad, C. M. and A. K. Sen, 1993. Study the effect of four different growth promoters on performance of broiler. Poult. Advisor, 26 (7): 49-52.

Samarth, V. R.; D. G. Jagtap., N. P. Dakshinkar., M. V. Nimbalkar and M. D. Kothekar, 2002. Effect of Ashwaganha root powder (Withania somnifera) on performance of broiler.India Vet. J., 79:733-734.

Singh, J.; K. M. Koley, K. Chandrakar and N. S. Pagrut, 2013. Effects of aloe vera on dressing percentage and haematobiochemidal parameters of broiler chickens. Veterinary World, 6 (10): 803806.

Talebi A.; S. Asri-Rezaei, R. Rozeh-Chai, R. Sahraei, 2005. Comparative studies on hematological values of broiler strains. International Journal of Poultry Science, 4 (8): 573-579.

Trincha S., C.; A. Cernea, Arion and L. Ognean, 2012. The relevance of mean blood samples in hematological investigations of broiler chickens. Veterinary Medicine, 69(1-2) 209-214.

\section{How to cite this article:}

Gadekar, S. D., S. D. Chavan and Nage, S. P. 2020. Haematological Indices of Vanraja Poultry Birds Fed Aloe vera (Aloe barbadensis) and Neem (Azadirachta indica) Leaves Powder. Int.J.Curr.Microbiol.App.Sci. 9(11): 3437-3444. doi: https://doi.org/10.20546/ijcmas.2020.911.410 